\title{
Challenge of educational leaders' spirituality in the millennium age
}

\author{
Yan J.B. Parrangan \\ \{yanparrangan1@gmail.com\} \\ Sekolah Tinggi Teologi Pelita Kebenaran Medan ${ }^{1}$
}

\begin{abstract}
The society in a nation has a tool in their hands that can shape the life of a nation, namely education. Education leaders, which include education foundations must make a choice whether to conduct secular or spiritual education. Spiritual education may seem to be limited, in that it must comply with the biblical teachings and biblical principles. Secular education on the other hand allows liberty to include anything that people consider worthy. However, demoralization is connected to secularization of society, and within a matter of time, various ideologies will be introduced in society, causing confusion and ultimately chaos. The current studyevaluates the consequences of secular and spiritual education. This research uses a qualitative descriptive approach. The method is primarily library research. The data are views of spirituality, secular education and spiritual education taken from sources which are in literature. Analysis was made based on contrastive analysis in the context of current and future implementations of education. It is concluded that society must revert back to well grounded-spiritual education.
\end{abstract}

Keywords:Leader's, Millenium age, educational

\section{Introduction}

Leadership is critical in determining the future and direction of an a community, an organization, and even a nation. The rapid development in an era accompanied by inventions, new forms of life and thinking pose a challenge for the implementation of education in the Millennium era. The basic pattern of education still prioritizes life modeling as the easiest and most effectiveway of learning is through a role model. Behavioral changes in the development of the millennial generation, characterized by violence and intolerance,present a problem that must be resolved immediately in order to offer a real hope for the future of this generation.

The Government of Indonesia, through the Ministry of Education and Culture and the Ministry of Research, Technology and Higher Education (RISTEKDIKTI) have compiled the most up to date curriculum by promoting character building to help students regard moral matters as well as pursuing academic capabilities. This completes cognitive, affective and psycho-motoric aspects which are fundamental in the purposes of education.

The Indonesian society is strongly attached to religious beliefs, with five religions and one spiritual belief in the Almighty God as a guide to worship for citizens. However, in society there is also the misuse of beliefs and religions ridden by agendas of selfish political interests.

Leaders in all sectors of life intersect with the world of education. In particular teachers, lecturers, educational staff, school leaders, deans or school leaders and foundations that oversee 
the management of schools, all have very crucial roles to play in transforming education in order to give birth to a generation with morals, virtuous and commendable character.

Socio-political changes in the national life in the reformation era that allowed dynamics in the lives of the people and the nation affected life in the midst of the wave of change. Changes in the mental views and perspectives shifted toward cost-effectiveness, oriented to material gain and fulfilling worldly pleasures that foster secular ungodly culture in modern life in the $20^{\text {th }}$ century. All this was accompanied by modern lifestyles entering a new era $21^{\text {st }}$ century.

The widespread entry of foreign culture and a pluralistic world community culture brought about by the processes of social, economic, political, and cultural relations formed a global social order that became more evident in the life of the nation (Islamic spirituality, Aksara Borneo, 25 Dec 2012).

\section{Method}

This research uses a qualitative descriptive approach. The method is primarily library research. The data are views of spirituality, secular education and spiritual education taken from sources which are in literature. Analysis was made based on contrastive analysis in the context of current and future implementations of education.

\section{Results and Discussion}

\subsection{The responsibility of every citizen}

The responsibility of every citizen to abide in togetherness as part of a great nation is immensely great. This implies a willingness to comply withthe rules of self-responsibility as citizens who obey the rules relating to obligations to the state, namely the financial contribution of each citizen through payment of taxes, reporting of state administrators' assets and all rules of retribution which are the pillars of a nation's financial journey.

The Bible as a Christian holy book records various social obligations that must be fulfilled by all citizens as part of the community of life that relates to one another. Leaders as individuals who are trusted to oversee the implementation of community responsibility have a central role. There is a great demand for leaders to fulfilling all rules that have been set for community life.

The qualifications of leaders who will be trusted to represent their communities in developing joint policies and overseeing their implementation are clearly recorded in the Book of Exodus 18: 21(New King James Version), "Moreover you shall select from all the people able men, such as fear God, men of truth, hating covetousness; and place such over them to be rulers of thousands, rulers of hundreds, rulers of fifties, and rulers of tens."Based on this principle, several aspects of qualifications can be derived.

a. "Able" (competent)

b. "Fear God"

c. "Men of truth" (trustworthy)

d. "Hating covetousness" (will not accept bribes)

Qualifications of accountabilitythat can demonstrate responsibility for all actions and a willing to be step down from authority in the cases where deviation from the biblical qualifications are found. This is comparable with 1 Samuel 12:3-5 (New International version). 
Here I stand. Testify against me in the presence of the Lord and his anointed. Whose ox have I taken? Whose donkey have I taken? Whom have I cheated? Whom have I oppressed? From whose hand have I accepted a bribe to make me shut my eyes? If I have done any of these things, I will make it right."4 "You have not cheated or oppressed us," they replied. "You have not taken anything from anyone's hand."5 Samuel said to them, "The Lord is witness against you, and also his anointed is witness this day, that you have not found anything in my hand." "He is witness," they said.

e. The responsibility of fostering the unit, namely the nuclear family as a form of fulfilling the most basic obligations to instill religious values and beliefs that become the moral foundation of the education of the current generation. A leader is required to be able to lead at the smallest institution in life, namely the family according to (New King James Version) 1 Timothy 3: 2-4

"A bishop then must be blameless, the husband of one wife, temperate, sober-minded, of good behavior, hospitable, able to teach; 3 not given to wine, not violent, not greedy for money, but gentle, not quarrelsome, not covetous; 4 one who rules his own house well, having his children in submission with all reverence"

Leaders with the qualifications of a good family head, respected and respected by their children.A leader with mature self-control will be able to manage a larger organization and community.

\subsection{The development of education in the Millennium era}

According to Lebar (2006: 30-31) If the potential of all Christians is developed from the beginning of their lives, adults in the church will produce Christian life, Christian witness, Christian literature, Christian art, Christian music and expertise in all areas, resulting indecent work as followers of the Son of God. This shows that the impact of education in the religious community is a very influential foundation for the future development of individual's life in actualizing his/her life in the community. In the middle of the $20^{\text {th }}$ century, a September 1954 edition of the "Eternity" magazine p.10 revealed the differences in spirituality that exist within Christian leaders in Britain and in America. Christian leaders in America found a lack of spiritual depth which was a sad condition. Now in the $21^{\text {st }}$ century there are so many behavioral deviations and character impairment in the American society. The lack of contribution of discoveries and secular materialistic principles become color people's lives in America. The direction of the development of education in the millennial era is a very important issue. The teachings of truth originating from the Bible must still guard developments in social life. Technology that is rapidly advancing accompanied by various changes that are very fast becomes a challenge for teaching truth. Two macro educational cultures can be formed, namely education based on faith (Kingdom mindset) or vice versa. Secular education that leads to humanism that glorifies humanity.

a. Education based on faith

Education based on faithhas the criteria that regards the teachings of God as a source of knowledge. The foundation of various developments in education is human respect for God as a source of life. Humans are responsible for exploring the wealth of God's creation used to the interests of mankind together under the piety of the Creator.

b. Secular education

A philosophy of life that assumes that the highest knowledge exists in humans and can be studied using human findings and limiting the involvement of the Creator in human life. The norm of life that separates humans from the law of God's law. 


\section{Conclusion}

Education plays the role of shaping society, in idealogical, cultural and intellectual realms. Leaders in history have often directed and shaped society in the way that they desire by using education, or education institutions in particular. Without spiritual or religious education, it is inevitable that society will encounter the consequences of secularism. This alludes to the picture that mankind was granted order, but mankind sawa this as a problem because it poses on him a limitation. He then opted to do things his way and later discovered that a greater number problems were usherd into his life. The problem that was initially perceived turns out to be minor.

Society therefore must be wise in making their choice. If they choose to do things their way or in other words, the secular way, they must later face the consequences of a problematic degenerate society. If they choose to do things God's way, in other words, religious education, they will have order in their lives.

\section{References}

[1] Lebar, L.E. (2006).Education that is Christian.Penerbit Gandum Mas: Malang

[2] Islamic spirituality, Borneo characters, 25 Dec 2012)

[3] New King James Version. https://www.biblegateway.com/passage/?search=2+Timothy +3\%3A1$4 \&$ version $=\mathrm{NKJV}$

[4] New King James Version. https://www.biblegateway.com/passage/?search=Exodus+ $18 \% 3 \mathrm{~A}+21 \&$ version $=\mathrm{NKJV}$

[5] New International version. https://www.biblegateway.com/passage/?search=1+Samuel+ $12 \% 3 \mathrm{~A} 3-5 \&$ version$=\mathrm{NIV}$ 